Journal of Environmental Sciences (JES)

Institute of Environmental Studies and Research, Ain Shams University

Zabib, Maha et al.

\title{
USE OF SOME ENVIRONMENTALLY SAFE COMPOUNDS DURING CONDITIONING OF WHEAT BEFORE MILLING TO PRODUCE HEALTHY SAFE BAKERY PRODUCTS
}

\author{
Maha M. Zabib ${ }^{(1)}$; Farouk M. El-Talawy ${ }^{(1)}$; Hamdy M. Ebeid ${ }^{(2)}$ \\ Mohamed A. El-Nawawy ${ }^{(2)}$
}

1) Institute of Environmental Studies and Research, Ain Shams University

2) Faculty of Agriculture, Ain Shams University

\begin{abstract}
Wheat is milled into flour or semolina using the conditioning-roller milling process. During the conditioning process the fungal counts and the mycotoxins production increased. The effect of use some conditioning compounds before milling of wheat on mold and aflatoxin production was investigated. Acetic acids at a concentration of $(0.05 \%)$ inhibited completely the growth of Aspergillus flavus and no toxins were detected. Concentrations of ascorbic acid were not sufficient for mold and aflatoxin production.

The results suggest the use of propionic and acetic acids for inhibiting fungal growth on wheat grains or wheat flour after milling. A wide range of protein content $(10.70-11.20 \%)$ of flours was recorded. Wet and dry gluten contents of wheat flour samples were consistent with their protein contents. Data indicated that treated wheat with acetic acid in $0.05 \%$ concentration during conditioning produced wheat flours has more suitable properties for bread- making than the other treatment.
\end{abstract}

Key words: spergillus, Aflatoxins, Fungicide, Propionate, Acetate, Ascorbate, wheat, conditioning, milling. 
Journal of Environmental Sciences (JES)

Institute of Environmental Studies and Research, Ain Shams University

Zabib, Maha et al.

\section{INTRODUCTION}

Mycotoxins are ubiquitous contaminant and are difficult to prevent or to diminish. Therefore, it is important to establish the contributions of processing steps to eliminating mycotoxins in the production of safer foods. In the marketplace, mycotoxins can be a hurdle to international trade, leading to increased regulation of foods and feeds that may contain them and removal from the market of commodities not meeting regulatory limits. When present in foods in sufficiently high levels, these fungal metabolites can have toxic effects that range from acute (for example, liver or kidney deterioration), to chronic (for example, liver cancer), mutagenic, and teratogenic; and resulting symptoms range from skin irritation to immuno suppression, birth defects, neurotoxicity, and death (Verma, 2018).

Cereals are major source of calories consumed by people worldwide on a daily basis. Several species of cereals are grown, among which wheat cultivation plays a crucial role. Wheat is milled into flour or semolina using the conditioning-roller milling process. The milling process starts with cleaning operation to remove metals, chaff, glumes, stones, and other foreign material, including other grains. The cleaned grain is conditioned before milling, with the aim of a more efficient bran separation, to soften the endosperm so as to enhance its gradual reduction in particle. size, and to improve sieving efficiency. Wheat is usually tempered with water sprayed on the grain being conducted in a conveyor. The water is evenly distributed on the surface of the grain. Then the wheat is transported into a tempering bin for 
conditioning for several hours. During this time, kernels absorb the water, which concentrates in the external part of the grain (germ and pericarp). When kernels are hard or vitreous, such as durum, and kernels contain low moisture, the tempering operation is performed in two sequential steps. The different classes of wheat are tempered for different times and final moisture content. Hard wheat requires more moisture and conditioning time than soft wheat. Generally, hard wheat is conditioned for 12-24 hrs and $16.5 \%$ moisture, and soft for 5-15 hrs and 15\%-15.5\% moisture. Durum requires the highest moisture $(17 \%-17.5 \%)$ and tempering times of 12-24 hrs. Durum wheat conditioning is usually different from that for bread wheats since more moisture is desired in bran than in the endosperm. At low moisture level bran becomes brittle and is readily abraded with increases the number of specks which may be found in the semolina (Serna-Saldivar, 2010). During this process the fungal counts and the mycotoxins production increased. Therefore temperature and humidity during wheat conditioning must be controlled to minimize the grain healthy and prevent food poisoning. Therefore, different strategies have been developed to prevent fungal growth on food, one of which is supplementation with antifungal compounds. Thus, the objective of the present work was to investigate the effectiveness of some organic acids as antifungal compounds to control the fungal pollution in the imported wheat grains and to evaluate and determine the effective concentration which can be used as fungicide for wheat grains during conditioning process. 
Journal of Environmental Sciences (JES)

Institute of Environmental Studies and Research, Ain Shams University

Zabib, Maha et al.

\section{MATERIALS AND METHODS}

Materials: Wheat (imported varieties from Russia) was obtained from one location (Cairo) from each location one sample and from different Companies since 2017.

Aspergillus flavus NRRL (20521) was obtained from the Agricultural Research Service Culture Collection. Natural Center for Agricultural Utilization Research (Pretoia, Illinois, USA).

Media and Reagents: The following solutions and media were used for mold enumeration and identification: Peptone water, Rose Bengal chloramphenical agar (Biolife, Italy).

Standard aflatoxins: $B_{1}, B_{2}, G_{1}$ and $G_{2}$ were obtained from Sigma chemical company (St. Louis, MO USA). Precoated TLC plates $(0.2 \mathrm{~mm}$ thick, 20x20 $\mathrm{cm}$ ) coated with Silica gel/60, were obtained from Merck (Darmstadt, Germany).

Organic acids: Propionic acid (E280) for synthesis (Cat. No.800605) (Merck, Germany). Ascorbic acid (Vit. C) for synthesis (Cat. No.800269) (Merck, Germany). Acetic acid (E260) (Cat. No.100063) (Merck, Germany).

Methods: Sampling and grain quality testing were carried out according to USDA, (2013). Measurement of the temperature, moisture, air conduction and humidity in silos under investigation were carried out according to USDA, (2013). Estimation of infested wheat was investigated according to USDA, (2013). 
A twenty Kgs of each wheat sample used in this investigation was stored 90 days at temperature $25^{\circ} \mathrm{C}$ and relative humidity less than $62 \%$ According to the methods described in USDA, (2013). At the end of storage period wheat sample was cleaned mechanically to remove dirt, dockage, imparters and other strange grains by Carter Dockage Tester According to the methods described in USDA, (2016). The wheat samples were tempered to $16.5 \%$ moisture and allowed to conditioning for 24 hours, then milled by Laboratory mill CD1 auto Chopin According to the methods described in AACC method (2000). The extraction rate of any flour sample was adjusted to recurred rate (72\% extraction).

\section{Analytical methods:}

Physical properties: Cleanliness, dockage, shrunken and broken, foreign materials, total damaged kernels and total defects were separated and determined manually (hand picking). Test weight pound per bushel, Test weight $\mathrm{P} / \mathrm{B}=(\mathrm{Kg} /$ Hectoliter $) \div 1.278$ according to USDA, (2016). A thousand kernel weights were determined by counting the kernels in a $10 \mathrm{~g}$ wheat sample AACC method, (2000). Wet and dry gluten and falling number were determined according to A.O.AC., (2012).

Chemical and microbiological analysis: Moisture, crude protein, ash, crude fiber, fat and tannin acid were determined according to A.O.AC., (2012) and USDA, (2013). The nitrogen free extractan (N.F.E) was calculated by difference. 
Journal of Environmental Sciences (JES)

Institute of Environmental Studies and Research, Ain Shams University

Zabib, Maha et al.

Total mold count \& Fungal identification were carried out using Rose Bengal chloramphenical agar and incubated for 5-7 days at $25^{\circ} \mathrm{C}$. Fungal identification was performed for isolated fungi according to Samson et al. (1995) and Klich, (2002).

Estimation of Aflatoxins content was carried out using the A.O.A.C. method (1990 and 1995).

Preparation of Asp. flavus NRRL (20521) spores: wheat was deliberately infected with Aspergillus flavus NRRL (20521) which was grown on malt extract agar slant and characterized by crop of green conidia. The spores were scraped by adding sterile distilled water to the surface growth on the slants and an aliquot from the resulting spore suspension $(1 \mathrm{ml})$ was added to sterile conical flasks (2 liter) containing the wheat under test

\section{Experiments:}

Experiment (1): Grading of wheat and determination of fungal growth and toxin production after 90 days storage. From each storage location, samples were taken periodically monthly for three months and after 30,60 and 90 days of storage at $25^{\circ} \mathrm{C}$. The temperature, moisture content and humidity were recorded and total fungal counts were determined. The aflatoxins content were determined after 90 days of storage.

Experiment (2): Effect of organic acids on fungal growth and Aflatoxins production in stored wheat samples: One $\mathrm{kg}$ and half of wheat (18\% moisture content) equally divided into 14 sterile Erlenmeyer flasks; The organic acids used in this study were added to wheat sub samples with different dilution 
Journal of Environmental Sciences (JES)

Institute of Environmental Studies and Research, Ain Shams University

Zabib, Maha et al.

rates $(0.02 \%, 0.03 \%$, and $0.04 \%)$ for Propionic acid, $(0.04 \%, 0.05 \%$ and $0.06 \%)$ for acetic acid, $(1 \%, 2 \%$ and $3 \%)$ for ascorbic acid. One flask was left without acid addition and used as control. Ten grams were withdrawn from each flask at (zero time) and after 30,60, and 90 days to estimate the effect of the type of organic acid on fungal growth and aflatoxins production.

\section{RESULTS AND DISCUSSION}

\section{Wheat kernels:}

Physical properties of Russian wheat kernels: Wheat grades are based on government standards. The grade standards include bushel weight, heat damage, foreign matter, broken kernels, and the presence of wheat from other classes D'Appolonia and Emeritus (1996). Mean values of physical properties of Russian wheat kernel varieties are presented in Table (1). Moisture content was $(11.60 \%)$. The test weight was 61.75 pound per bushel. Test weight is considered as one of the most important tools in wheat grading system. The results indicated that the foreign material was $0.02 \%$ and the both shrunken and broken kernels in Table (1) were $(0.44 \%)$. Damaged kernels which consists of heat damage and total damage. Russian wheat had high total damage kernels percentage $(1.86 \%)$. From Table (1) it can be noticed that the Russian wheat haven't heat damage. Additionally, sample is free from insect and ok odor. The results in Table (1) showed that wet, dry gluten, hydration ratio and gluten index for the wheat meal are $(24.7 \%),(8.2 \%),(201.22 \%)$ and $(77.7 \%)$, receptivity. These results agree with the results obtained by 
Journal of Environmental Sciences (JES)

Institute of Environmental Studies and Research, Ain Shams University

Zabib, Maha et al.

Nagarajan, (2005) who reported that the standard mill quality wheat, medium grain size and appearance, medium hard, dry gluten $9 \%$, protein $>10 \%$, > HLW 76, seed moisture $11 \%$, total defects $6 \%$, extraction efficiency $<69 \%$, sedimentation value $<40$. Bold and lustrous grain, dry gluten $9 \%$, protein $>$ $12 \%$, HLW approx. 80, seed moisture 11\%; extraction efficiency is approx. $70 \%$. It is suitable for a variety of fermented and non-fermented breads according to the Egyptian stander no. 1601/1986. Results in Table (1) indicated also that the 1000 kernels weight is 33.0 gm for Russian wheat. Dick and Motsuo (1988) reported that wheat samples with low 1000 kernels weight tend to give low test weight. A strong relationship between test weight and 1000 kernels weight was also reported by Dexter et al., (1987). Falling number which indicate the enzyme activity of Alfa amylase was also studied.

The Russian wheat had high falling number (351 sec.) and lowest enzyme activity. This decrease in falling number may be due to the increase of Alfa amylase activity of lemma layer particles. Alpha amylase activity depends on weather conditions, especially precipitation and mineral fertilizer. Our results were similar to the results obtained by Pasha (2006) who reported that, the falling number is ranged from 243-648 in fifty different wheat varieties during 2004-05. These results are also in agreement with those obtained by (Debbouz et al; 1995). Additionally Gupta et al., (2002) reported that, the wheat grain classification is essential for trade and quality control as the buyer is able to understand the utilities of the supply and negotiate the price. The approach rests on two parameters, namely the physical purity or 
Journal of Environmental Sciences (JES)

Institute of Environmental Studies and Research, Ain Shams University

Zabib, Maha et al.

"Grade" and the other grouping called "Class" which is based on the grain quality traits. These results are in agreement with those obtained by Muhammad et al., (2009). However, wheat sample had grade one according to U.S department of agriculture (2006 D).

Chemical composition of Russian wheat kernel: Chemical compositions of wheat kernels used in this study are given in Table (6). The wheat moisture content of Russian wheat is $11.6 \%$. This low moisture content is suitable for storage and wheat would be less prone to microbial attack. Moisture content is dependent on genetic makeup of wheat varieties and is largely influenced by agronomic and climatic conditions (Mahmood, 2004). Regarding the protein content which considers an important criterion while considering the wheat quality, Russian wheat had the highest protein content $(11.70 \%)$. This protein content is a key factor in determining the suitability of wheat for different products and in many areas of the world it is a fundamental criterion for establishing the economic value of wheat. The quantity of protein depends on the growing conditions, however, variations in protein content among wheat varieties are due to differences in their genetic makeup as well as differences in environmental and production conditions prevailed during growth stages (Randhawa, 2001). Our results are in agreement with result obtained by (Charles, 2005) who reported that protein content of hard red winter wheat ranged from $13 \%$ to $15 \%$ and for soft white winter it was $10 \%$ to $12 \%$. The nitrogen free extracts (NFE) percentage is ranged from $71.97 \%$. Additionally, Russian wheat had low fat percentage (0.08\%), low ash content 
Journal of Environmental Sciences (JES)

Institute of Environmental Studies and Research, Ain Shams University

Zabib, Maha et al.

(1.67\%). The results of fiber showed that the Russian wheat had high value $(2.98 \%)$.

Table (1): Physical properties of Russian wheat kernels

\begin{tabular}{|c|c|}
\hline Wheat variety & Russian Wheat \\
\hline \hline M.C\% & 11.60 \\
\hline T.W p/b & 61.75 \\
\hline F.M\% & 0.02 \\
\hline Sh.\& B.N\% H.D & 0.44 \\
\hline T.D & Zero \\
\hline \multirow{2}{*}{ D.K\% } & 1.86 \\
\hline Odor & Ok \\
\hline Insect & Free \\
\hline Weight per 1000 kernels gm & 33.0 \\
\hline Hardness\% & 61.0 \\
\hline Colour & Red \\
\hline Wet gluten $\%$ & 24.7 \\
\hline Dry gluten \% & 8.2 \\
\hline Hydration ratio & 201.22 \\
\hline Gluten index $\%$ & 77.7 \\
\hline Falling Number sec & 351.0 \\
\hline Grade & 1 \\
\hline
\end{tabular}

T.W = Test weight, $\mathrm{p} / \mathrm{b}=$ Pound per Bushel (American unit), M.C = Moisture Content, F.M = Foreign Material, Sh. \& B.N = Shrunken \&Broken kernels, D.K = Damage Kernels, H.D = Heat Damage, T.D = Total Damage, RussW= Russian Hard Red Wheat.

Table (2): Proximate analysis of Russian wheat kernels

\begin{tabular}{|c|c|}
\hline Wheat variety & Russian Wheat \\
\hline M.C & 11.6 \\
\hline Protein\% & 11.7 \\
\hline Fat $\%$ & 0.08 \\
\hline Ash\% & 1.67 \\
\hline Fiber\% & 2.98 \\
\hline NFE\% & 71.97 \\
\hline Total caloric values k cal & 335.4 \\
\hline
\end{tabular}

NFE = Nitrogen free extracts, 
Aflatoxin content of Russian wheat kernels: Wheat can be affected by the most frequent toxigenic fungi. In Europe are Aspergillus, Penicillium and Fusarium species. They produce aflatoxin B1 as well as Ochratoxins and Zearalenone, Fumonisin B1, T-2 toxin, HT-2 toxin and deoxynivalenol (vomitoxin), which are of increasing concern in human health Edmond, (2002). Results in Table (3) show that aflatoxin content in Russian wheat kernel was under detection limit $(0.5 \mathrm{ppb})$ Aflatoxin content value was within the safe limit $(50 \mathrm{~g} / \mathrm{kg})$ according to the recommendations made by FAO/IAEA, (2001).

Table (3): Aflatoxin content in Russian wheat kernels

\begin{tabular}{|c|c|c|}
\hline \multicolumn{2}{|c|}{ Wheat } & UkW \\
\hline \multicolumn{2}{|c|}{ Ochratoxin ppb } & $*$ \\
\hline \multicolumn{2}{|c|}{ Zearalenone $\mathrm{ppb}$} & $*$ \\
\hline \multicolumn{2}{|c|}{ Fumonisin ppb } & $*$ \\
\hline \multirow{5}{*}{ Aflatoxin ppb } & B1 & $*$ \\
\hline & B2 & $*$ \\
\hline & G1 & $*$ \\
\hline & G2 & $*$ \\
\hline & Total & $*$ \\
\hline
\end{tabular}

*= Under detection limit (0.50ppb),

Isolated fungal species from Russian wheat kernels: Growth of fungi on the grain is the most common cause of spoilage of stored grain and the mean counts of the fungi colonies ranged from 275 to $1277 \mathrm{CFU} \mathrm{g}{ }^{-1}$ (Vellaichamy, 2008). The commonly isolated fungi were species of Aspergillus, Fusarium, Penicillium, Alternaria and Mucor. Aspergillus was the genus most detected at high frequency in all of the samples. The results of isolated fungal species 
Journal of Environmental Sciences (JES)

Institute of Environmental Studies and Research, Ain Shams University

Zabib, Maha et al.

for imported kernels (Russian wheat) before storing are present in Table (4). Data show that total mold count was $2.48 \log$ CFU /g. Additionally, Riba et al., (2008) reported that the dominant genus was Aspergillus, predominantly A. flavus, A. niger and A. versicolor and the other isolated species were A. ochraceus, A. alliaceus, A. carbonarius, A. terreus, A. fumigatus, A. candidus and Aspergillus spp whereas, the occurrence and the levels of the genus Penicillium, Fusarium, Alternaria and Mucor were substantially lower than those of Aspergillus. Our results show high levels of Aspergillus (66 to 84\%), especially A. flavus, but A. niger whereas, other fungi were isolated at relatively low percentages.

Effect of some organic acids on the fungal growth and aflatoxins production on wheat grains: As shown in table (5) control and all treated samples were under detection limit $(0.5 \mathrm{ppb})$ for aflatoxin samples in the beginning of the storage period at $25^{\circ} \mathrm{C}$. Also the highest mold count was $8.33 \mathrm{log} \mathrm{cfu} / \mathrm{g}$ for the control samples. Generally the effect of organic acids treatments is not remarkable at the beginning of the storage period.

The data in table (6) presents the effect of some organic acids used as fungicides for imported wheat grains on mold growth and Aflatoxins production after 30 days of the storage at $25^{\circ} \mathrm{C}$. It could be noticed that the increase in propionic and acetic acid concentrations had remarkable effect on mold count. The increase of acid concentrations decreased the mold count. The highest decrease in mold count was recorded in samples treated with acetic acid followed by propionic acid. On the contrary the use of increased 
concentrations of ascorbic acid had the least effect on mold growth. The use of $0.04 \%$ concentrations of acetic acid had the highest effect in decreasing mold counts after 30 days of the storage

Table (4): Isolated fungal species from Russian wheat kernels

\begin{tabular}{|c|c|}
\hline \multirow{2}{*}{ Isolated species } & Wheat \\
\cline { 2 - 2 } & Russian Wheat \\
\hline Mucor hiemalis & + \\
\hline Rhizopus oryzae & + \\
\hline Asp. Candidus & + \\
\hline Asp. Flavus & + \\
\hline Asp. Ochraceus & + \\
\hline Pen. Citrinum & + \\
\hline Asp. parasiticus & + \\
\hline Cladosporium macrocarpum & + \\
\hline Emericella nidulans & 2.48 \\
\hline Total Mold count log cfu/g & \\
\hline
\end{tabular}

Table (5): Effect of some organic acids used as fungicide for imported wheat grains on mold growth and aflatoxins production at the beginning of storage for 90 days at $25^{\circ} \mathrm{C}$

\begin{tabular}{|c|c|c|c|c|c|c|c|}
\hline \multirow{2}{*}{ Acid } & \multirow{2}{*}{$\begin{array}{c}\text { Concentrations } \\
\%\end{array}$} & \multirow{2}{*}{$\begin{array}{c}\text { Mold Count } \\
\log \mathrm{cfu} / \mathrm{g}\end{array}$} & \multicolumn{5}{|c|}{ Aflatoxin ppb } \\
\hline & & & $\mathbf{B}_{1}$ & $\mathbf{B}_{2}$ & $\mathbf{G}_{1}$ & $\mathbf{G}_{2}$ & Total \\
\hline \multirow{3}{*}{ Propionic } & 0.02 & 2.3 & ** & ** & +* & "* & $*$ \\
\hline & 0.03 & 0.82 & $*$ & $*$ & $*$ & $*$ & $*$ \\
\hline & 0.04 & $<1$ & $*$ & $*$ & $*$ & $*$ & $*$ \\
\hline \multirow{3}{*}{ Acetic } & 0.04 & $<1$ & $*$ & $*$ & $*$ & $*$ & $*$ \\
\hline & 0.05 & $<1$ & $*$ & $*$ & $*$ & $*$ & $*$ \\
\hline & 0.06 & $<1$ & $*$ & $*$ & $*$ & $*$ & $*$ \\
\hline \multirow{3}{*}{ Ascorbic } & 1 & 2.18 & $*$ & $*$ & $*$ & $*$ & $*$ \\
\hline & 2 & $<1$ & $*$ & $*$ & $*$ & $*$ & $*$ \\
\hline & 3 & 1.76 & $*$ & $*$ & $*$ & $*$ & $*$ \\
\hline Control & 0 & 8.33 & $*$ & $*$ & $*$ & $*$ & $*$ \\
\hline
\end{tabular}

$*=$ Under detection limit $(0.5 \mathrm{ppb})$ 
Table (7) shows the effect of some organic acid used as fungicides for imported wheat on mold growth after 60 days of the storage at $25^{\circ} \mathrm{C}$. The use of acetic acid had the highest effect on mold growth when compared with all other treatments. Also the increase of organic acid concentrations decreased the mold growth after 60 days of storage at $25^{\circ} \mathrm{C}$. Furthermore, fumaric acid had reverse effect on mold growth as compared with control wheat samples. Aflatoxins production for B1, B2, G1, G2 and total Aflatoxins were not determined in all samples after 60 days of the storage at $25^{\circ} \mathrm{C}$. Generally the use of organic acid $0.05 \%$ concentrations of propionic acid had the highest effect on mold growth and mold counts were less than $1.0 \log \mathrm{cfu} / \mathrm{g}$.

Table (6): Effect of some organic acids used as fungicide for imported wheat grains on mold growth and aflatoxins production after 30 days of storage at $25^{\circ} \mathrm{C}$.

\begin{tabular}{|c|c|c|c|c|c|c|c|}
\hline \multirow{2}{*}{ Acid } & \multirow{2}{*}{$\begin{array}{c}\text { Concentrations } \\
\%\end{array}$} & \multirow{2}{*}{$\begin{array}{l}\text { Mold Count } \\
\log \text { cfu/g }\end{array}$} & \multicolumn{5}{|c|}{ Aflatoxin ppb } \\
\hline & & & $\mathbf{B}_{1}$ & $\mathbf{B}_{2}$ & $\mathbf{G}_{1}$ & $\mathbf{G}_{\mathbf{2}}$ & Total \\
\hline \multirow{3}{*}{ Propionic } & 0.02 & 1.47 & - & - & - & - & - \\
\hline & 0.03 & 1.43 & - & - & - & - & - \\
\hline & 0.04 & 1.17 & - & - & - & - & - \\
\hline \multirow{3}{*}{ Acetic } & 0.04 & 1.1 & - & - & - & - & - \\
\hline & 0.05 & 1.43 & - & - & - & - & - \\
\hline & 0.06 & 1.52 & - & - & - & - & - \\
\hline \multirow{3}{*}{ Ascorbic } & 1 & 7.68 & - & - & - & - & - \\
\hline & 2 & 4.31 & - & - & - & - & - \\
\hline & 3 & 2.12 & - & - & - & - & - \\
\hline Control & 0 & 7.96 & - & - & - & - & - \\
\hline
\end{tabular}

-= Under detection limit $(0.5 \mathrm{ppb})$ 
Table (7): Effect of some organic acids used as fungicide for imported wheat grains on mold growth and aflatoxins production after 60 days of storage at $25^{\circ} \mathrm{C}$

\begin{tabular}{|c|c|c|c|c|c|c|c||}
\hline \multirow{2}{*}{ Acid } & Concentrations & Mold Count & \multicolumn{5}{|c||}{ Aflatoxin ppb } \\
\cline { 4 - 8 } & $\mathbf{9}$ & $\mathbf{l o g} \mathbf{c f u} / \mathbf{g}$ & $\mathbf{B}_{\mathbf{1}}$ & $\mathbf{B}_{\mathbf{2}}$ & $\mathbf{G}_{\mathbf{1}}$ & $\mathbf{G}_{\mathbf{2}}$ & Total \\
\hline \multirow{3}{*}{ Propionic } & 0.02 & 1.11 & - & - & - & - & - \\
\cline { 2 - 8 } & 0.03 & 1.27 & - & - & - & - & - \\
\cline { 2 - 8 } Acetic & 0.04 & 0.5 & - & - & - & - & - \\
\cline { 2 - 8 } & 0.04 & 0.98 & - & - & - & - & - \\
\cline { 2 - 8 } & 0.05 & $<1$ & - & - & - & - & - \\
\hline \multirow{3}{*}{ Ascorbic } & 0.06 & 0.6 & - & - & - & - & - \\
\cline { 2 - 8 } & 1 & 8.11 & - & - & - & - & - \\
\cline { 2 - 8 } & 2 & 4.32 & - & - & - & - & - \\
\hline Control & 0 & 1.17 & - & - & - & - & - \\
\hline
\end{tabular}

$-=$ Under detection limit $(0.5 \mathrm{ppb})$

The data in table (8) showed that after 90 days of storage at $25^{\circ} \mathrm{C}$ of imported wheat the mold count ranged from 8.18 to $<1.0 \mathrm{log} \mathrm{cfu} / \mathrm{g}$.(in control and 0.04 and $0.05 \%$ acetic acid respectively.) also total aflatoxins determination ranged from $100 \mathrm{ppb}$ to $0.5 \mathrm{ppb}$. (For control and $0.05 \%$ acetic acids samples respectively). The use of 0.04 and $0.05 \%$ acetic acids decreased the mold count to less than $1.0 \mathrm{log} \mathrm{cfu} / \mathrm{g}$ and different aflatoxins determination was nil in the samples after 90days of storage at $25^{\circ} \mathrm{C}$., but the use of organic acid decreased the mold count and aflatoxins production when compared with control samples. Aflatoxins production was the lowest with the use of the $0.05 \%$ acetic acid followed by the used of $0.04 \%$ and $0.06 \%$ acetic acid. On the other hand, the use of ascorbic acid decreased aflatoxins 
production as compared with control samples after 90 days of storage at $25^{\circ} \mathrm{C}$.

Effect of some organic acids on the fungal growth and aflatoxins production on wheat flour quality: Effect of some organic acids used as fungicide for imported wheat on mold growth and aflatoxins production at the beginning of storage at $25^{\circ} \mathrm{C}$ is shown in table (9). Generally, the use of all organic acid even, $0.02 \%$ propionic acid and $1 \%$ ascorbic acid decreased the mold counts to less than $1.0 \log \mathrm{cfu} / \mathrm{g}$. Further more different aflatoxins production was not determined in all imported wheat at the beginning of storage at $25^{\circ} \mathrm{C}$.

Table (8): Effect of some organic acids used as fungicide for imported wheat grains on mold growth and Aflatoxins production during storage for 90 days at $25^{\circ} \mathrm{C}$

\begin{tabular}{|c|c|c|c|c|c|c|c|}
\hline \multirow{2}{*}{ Acid } & Concentrations & Mold Count & \multicolumn{6}{|c|}{ Aflatoxin ppb } \\
\cline { 4 - 8 } & $\mathbf{0}$ & $\mathbf{l o g} \mathbf{c f u} / \mathbf{g}$ & $\mathbf{B}_{\mathbf{1}}$ & $\mathbf{B}_{\mathbf{2}}$ & $\mathbf{G}_{\mathbf{1}}$ & $\mathbf{G}_{\mathbf{2}}$ & Total \\
\hline \hline \multirow{3}{*}{ Propionic } & 0.02 & 1.2 & 3.0 & 3.0 & 2.0 & 2.0 & 10.0 \\
\cline { 2 - 8 } & 0.03 & 1.17 & 1.3 & 1.0 & 1.1 & 1.0 & 4.5 \\
\cline { 2 - 8 } & 0.04 & 0.6 & 1.5 & 1.0 & 1.0 & 1.5 & 5.0 \\
\hline \multirow{3}{*}{ Acetic } & 0.04 & $<1$ & $*$ & $*$ & 0.6 & $*$ & 1.2 \\
\cline { 2 - 8 } & 0.05 & $<1$ & $*$ & $*$ & $*$ & $*$ & $*$ \\
\cline { 2 - 8 } & 0.06 & 0.91 & 1.0 & $*$ & 0.6 & 1.0 & 3.0 \\
\hline \multirow{3}{*}{ Ascorbic } & 1 & 7.74 & 40.0 & 25.0 & 10.0 & 5.0 & 80.0 \\
\cline { 2 - 8 } & 2 & 3.38 & 23.0 & 7.0 & 6.0 & 4.0 & 40.0 \\
\hline Control & 3 & 0.91 & 4.0 & 3.0 & 2.0 & 1.0 & 10.0 \\
\hline \hline
\end{tabular}

-= Under detection limit $(0.5 \mathrm{ppb})$ 
Table (9): Effect of some organic acids used as fungicide for imported wheat flour on mold growth and aflatoxins production at the beginning of storage at $25^{\circ} \mathrm{C}$

\begin{tabular}{|c|c|c|c|c|c|c|c|}
\hline \multirow{2}{*}{ Acid } & \multirow{2}{*}{$\begin{array}{c}\text { Concentrations } \\
\%\end{array}$} & \multirow{2}{*}{$\begin{array}{l}\text { Mold Count } \\
\log \mathrm{cfu} / \mathrm{g}\end{array}$} & \multicolumn{5}{|c|}{ Aflatoxin ppb } \\
\hline & & & $\mathbf{B}_{1}$ & $\mathbf{B}_{2}$ & $\mathbf{G}_{1}$ & $\mathbf{G}_{2}$ & Total \\
\hline \multirow{3}{*}{ Propionic } & 0.02 & 0.7 & ** & ** & ** & $*$ & $*$ \\
\hline & 0.03 & $<1$ & $*$ & $*$ & $*$ & $*$ & $*$ \\
\hline & 0.04 & $<1$ & $*$ & $*$ & * & $*$ & $*$ \\
\hline \multirow{3}{*}{ Acetic } & 0.04 & $<1$ & $*$ & $*$ & $*$ & $*$ & $*$ \\
\hline & 0.05 & $<1$ & $*$ & $*$ & $*$ & $*$ & $*$ \\
\hline & 0.06 & $<1$ & $*$ & $*$ & $*$ & $*$ & $*$ \\
\hline \multirow{3}{*}{ Ascorbic } & 1 & 0.7 & $*$ & $*$ & $*$ & $*$ & $*$ \\
\hline & 2 & $<1$ & $*$ & $*$ & $*$ & $*$ & $*$ \\
\hline & 3 & $<1$ & $*$ & $*$ & $*$ & $*$ & $*$ \\
\hline Control & 0 & $<1$ & $*$ & $*$ & $*$ & $*$ & $*$ \\
\hline
\end{tabular}

In table (10) mold count was $0.72 \log \mathrm{cfu} / \mathrm{g}$ in control. Also the use of $1.0 \%, 2.0 \%, 3.0 \%$ of ascorbic acid had no effect on mold count after 30 days of storage at $25^{\circ} \mathrm{C}$. On the contrary the use of $0.03 \%$ and $0.04 \%$ propionic acid and $0.05,0.06 \%$ acetic acid decreased the mold count to less than $1.0 \log$ cfu/g. Also the mold count decreased by increasing of propionic acid and acetic acid concentrations at treated samples. While Aflatoxins determination was not carried out in all samples. 
Table (10): Effect of some organic acids used as fungicide for imported wheat flour on mold growth and aflatoxins production after 30 days of storage at $25^{\circ} \mathrm{C}$

\begin{tabular}{|c|c|c|c|c|c|c|c|}
\hline \multirow{2}{*}{ Acid } & \multirow{2}{*}{$\begin{array}{c}\text { Concentrations } \\
\%\end{array}$} & \multirow{2}{*}{$\begin{array}{l}\text { Mold Count } \\
\log \mathrm{cfu} / \mathrm{g}\end{array}$} & \multicolumn{5}{|c|}{ Aflatoxin ppb } \\
\hline & & & $\mathbf{B}_{1}$ & $\mathbf{B}_{2}$ & $\mathbf{G}_{1}$ & $\mathbf{G}_{2}$ & Total \\
\hline \multirow{3}{*}{ Propionic } & 0.02 & 2.88 & - & - & - & - & - \\
\hline & 0.03 & $<1$ & - & - & - & - & - \\
\hline & 0.04 & $<1$ & - & - & - & - & - \\
\hline \multirow{3}{*}{ Acetic } & 0.04 & 0.5 & - & - & - & - & - \\
\hline & 0.05 & $<1$ & - & - & - & - & - \\
\hline & 0.06 & $<1$ & - & - & - & - & - \\
\hline \multirow{3}{*}{ Ascorbic } & 1 & 2.39 & - & - & - & - & - \\
\hline & 2 & 0.27 & - & - & - & - & - \\
\hline & 3 & 1.7 & - & - & - & - & - \\
\hline Control & 0 & 0.72 & - & - & - & - & - \\
\hline
\end{tabular}

$-=$ Not detected

Table (11) illustrates the effect of some organic acids used as fungicide for imported wheat on mold growth and aflatoxins production after 60 days of storage at $25^{\circ} \mathrm{C}$ mold count was the highest $(2.06 \log \mathrm{cfu} / \mathrm{g})$ in 0.02 propionic acid samples and with the use of $1.0 \%, 2.0 \%, 3.0 \%$ of ascorbic acid. On the contrary, mold count was less than $1.0 \mathrm{log} \mathrm{cfu} / \mathrm{g}$ in wheat samples treated with $0.04 \%$ propionic acid and $0.04,0.05,0.06 \%$ acetic acid. Aflatoxins determination (B1, B2, G1, G2 and total Aflatoxins) were not determined in all treated samples at the end of the storage period.

Table (12) illustrates the effect of some organic acids used as fungicide for imported wheat on mold growth and aflatoxins production after 90 days of storage at $25^{\circ} \mathrm{C}$. at the end of the storage period mold count was the highest 
(4.11 log cfu/g) in $1 \%$ ascorbic acid samples. On the contrary, mold count was less than $1.0 \log \mathrm{cfu} / \mathrm{g}$ in wheat samples treated with $0.04 \%$ propionic acid and $0.04 \%, 0.05 \%$ and of acetic acid. Aflatoxins determination (B1, B2, G1, G2 and total Aflatoxins) were under detection limit (0.5 ppb) in all treated samples even ascorbic acid, control and 0.02 propionic acid at the end of the storage period. The use of, $0.03 \%$ propionic acid and $0.05 \%$ acetic acid decreases the mold count to more than $2.0 \log \mathrm{cfu} / \mathrm{g}$ as compared with control samples.

Table (11): Effect of some organic acids used as fungicide for imported wheat flour on mold growth and aflatoxins production after 60 days of storage at $25^{\circ} \mathrm{C}$

\begin{tabular}{|c|c|c|c|c|c|c|c|}
\hline \multirow{2}{*}{ Acid } & \multirow{2}{*}{$\begin{array}{c}\text { Concentrations } \\
\%\end{array}$} & \multirow{2}{*}{\begin{tabular}{|c|} 
Mold Count \\
$\log \mathrm{cfu} / \mathrm{g}$
\end{tabular}} & \multicolumn{5}{|c|}{ Aflatoxin ppb } \\
\hline & & & $\mathbf{B}_{1}$ & $\mathbf{B}_{2}$ & $\mathbf{G}_{1}$ & $\mathbf{G}_{2}$ & Total \\
\hline \multirow{3}{*}{ Propionic } & 0.02 & 2.06 & - & - & - & - & - \\
\hline & 0.03 & 1.17 & - & - & - & - & - \\
\hline & 0.04 & $<1$ & - & - & - & - & - \\
\hline \multirow{3}{*}{ Acetic } & 0.04 & $<1$ & - & - & - & - & - \\
\hline & 0.05 & $<1$ & - & - & - & - & - \\
\hline & 0.06 & $<1$ & - & - & - & - & - \\
\hline \multirow{3}{*}{ Ascorbic } & 1 & 1.83 & - & - & - & - & - \\
\hline & 2 & 0.6 & - & - & - & - & - \\
\hline & 3 & 1.93 & - & - & - & - & - \\
\hline Control & 0 & 0.6 & - & - & - & - & - \\
\hline
\end{tabular}

- =Not detected 
Table (12): Effect of some organic acids used as fungicide for imported wheat flour on mold growth and aflatoxins production after 90 days of storage at $25^{\circ} \mathrm{C}$

\begin{tabular}{|c|c|c|c|c|c|c|c|}
\hline \multirow{2}{*}{ Acid } & Concentrations & Mold Count & \multicolumn{6}{|c|}{ Aflatoxin ppb } \\
\cline { 3 - 8 } & $\mathbf{0}$ & $\mathbf{l o g} \mathbf{~ c f u} / \mathbf{g}$ & $\mathbf{B}_{\mathbf{1}}$ & $\mathbf{B}_{\mathbf{2}}$ & $\mathbf{G}_{\mathbf{1}}$ & $\mathbf{G}_{\mathbf{2}}$ & Total \\
\hline \hline \multirow{3}{*}{ Propionic } & 0.02 & 2.49 & 1.5 & 0.9 & 0.6 & 1.0 & 4.0 \\
\cline { 2 - 9 } & 0.03 & 0.27 & $*$ & $*$ & $*$ & $*$ & $*$ \\
\cline { 2 - 9 } & 0.04 & 0.27 & $*$ & $*$ & $*$ & $*$ & $*$ \\
\hline \multirow{3}{*}{ Acetic } & 0.04 & 0.27 & $*$ & $*$ & $*$ & $*$ & $*$ \\
\cline { 2 - 9 } & 0.05 & $<1$ & $*$ & $*$ & $*$ & $*$ & $*$ \\
\cline { 2 - 9 } Ascorbic & 0.06 & 1.17 & $*$ & $*$ & $*$ & $*$ & $*$ \\
\cline { 2 - 9 } & 1 & 4.11 & 8.0 & 2.0 & 2.0 & 3.0 & 15.0 \\
\cline { 2 - 9 } & 2 & 0.6 & 0.7 & $*$ & $*$ & 0.9 & 2.0 \\
\hline Control & 3 & 1.22 & 1.0 & 0.6 & 0.6 & 0.8 & 9.0 \\
\hline
\end{tabular}

Effect of some organic acids used as fungicide for Russian wheat flour (72\% extraction) obtained from nine different treatment wheat kernels after storage:

Chemical composition after storage: Chemical composition of wheat flour prepared from different wheat kernels are shown in Table (13). Result indicted that chemical compositions of flour are different in all investigated samples. Moisture content is ranged from $11.5 \%$ (0.06\% acetic wheat flour) to $13.0 \%$ ( $0.03 \%$ propionic wheat flour). On the other hand, $0.04 \%$ propionic wheat flour had the highest protein content $(12.20 \%)$ and nitrogen free extract (74.30\%) compare to other samples, however control had the highest fat content compare to other studied samples. On other hand the $0.04 \%$ propionic wheat flour had the lowest ash content 
Table (13): Chemical composition of Russian wheat flour (72\% extraction) obtained from nine different treatment wheat kernels after storage

\begin{tabular}{|c|c|c|c|c|c|c|c|c|c|c|}
\hline \hline \multirow{2}{*}{$\begin{array}{c}\text { Wheat Flour } \\
\text { Treatment }\end{array}$} & \multicolumn{3}{|c|}{ Ascorbic } & \multicolumn{3}{c|}{ Propionic } & \multicolumn{3}{c|}{ Acetic } & \multirow{2}{*}{ Control } \\
\cline { 2 - 13 }$n$ & $\mathbf{2} \%$ & $3 \%$ & $0.02 \%$ & $0.03 \%$ & $0.04 \%$ & $0.04 \%$ & $0.05 \%$ & $0.06 \%$ & \\
\hline M.C & 12.6 & 12.7 & 12.8 & 12.9 & 13.0 & 12.7 & 11.9 & 11.6 & 11.5 & 12.0 \\
\hline Protein\% & 11.8 & 11.5 & 11.9 & 11.9 & 12.0 & 12.2 & 12.02 & 12.0 & 11.9 & 11.4 \\
\hline Fat \% & 0.05 & 0.04 & 0.03 & 0.03 & 0.03 & 0.02 & 0.04 & 0.04 & 0.03 & 0.06 \\
\hline Ash\% & 0.97 & 0.98 & 0.99 & 0.76 & 0.72 & 0.68 & 0.74 & 0.72 & 0.72 & 0.77 \\
\hline Fiber\% & 0.11 & 0.11 & 0.10 & 0.11 & 0.10 & 0.10 & 0.11 & 0.10 & 0.09 & 0.12 \\
\hline NFE\% & 74.47 & 72.26 & 4.18 & 74.3 & 74.15 & 74.3 & 75.01 & 75.54 & 75.76 & 73.65 \\
\hline $\begin{array}{l}\text { Total caloric } \\
\text { values k cal }\end{array}$ & 345.53 & 337.0 & 344.59 & 345.07 & 344.87 & 346.18 & 348.48 & 350.52 & 350.91 & 340.74 \\
\hline
\end{tabular}

Physicochemical properties after storage: The data in Table (14) showed that the highest starch damage was observed in $0.05 \%$ acetic wheat flour $(5.30 \%)$ while it was low in $2.0 \%$ ascorbic wheat $(5.17 \%)$. It is well known that dough derives its properties from the constituents of flour. The most important components are the protein, carbohydrates, lipids and water. Results from Tables (14) indicated that, the increase in protein content wasn't accompanied by the increase in wet and dry gluten contents. The $2 \%$ acetic wheat flour showed protein content of $11.80 \%$ and had the higher wet, dry gluten, index and hydration ratio $(25.30,8.60,98.9$ and $1.94 \%$ respectively) compare to other samples. The falling number values were ranged from 311 to $390 \mathrm{sec}$. The control wheat flour had the highest value $(390 \mathrm{sec}$.) where the $3 \%$ ascorbic wheat flour had the lowest value (311 sec.). Economic European community recommended that the falling number of flour should exceed than $230 \mathrm{sec}$ (Milatovie and Mondelli, 1991). Egyptian standard no. 1419/2006 of 
white flour for production of bread has the following requirement: protein content not less than $10.2 \%$, ash content not exceed than $0.9 \%$ and the falling number should exceed than $200 \mathrm{sec}$. Also, Egyptian standard no. 1649/2004 for durum wheat has the obligation that protein content of durum wheat not less than $10.5 \%$ and ash content not exceed than $1.3 \%$. From Table (14) it can be concluded that the percentage of sediment ranged from 29.8 to $31 \%$ and that the $2 \%$ ascorbic and 0.03 propionic wheat flour had the highest sediment ratio which good to produce bread. Table (14) also shows that, different varieties of wheat had the highest value of whiteness color $(0.03 \%$ propionic wheat flour) was (32.2). Flour color has a direct effect on crumb color and combines with crumb structure to influence crumb "brightness". Bleached bread flour is characterized by a typical white creamy color D'Appolonia and Emeritus (1996). 
Table (14): Physicochemical properties of Russain wheat flour (72\% extraction) obtained from nine different treatment wheat kernels after storage

\begin{tabular}{|c|c|c|c|c|c|c|c|c|c|c|c|}
\hline \multirow{2}{*}{\multicolumn{2}{|c|}{ Wheat Flour }} & \multicolumn{3}{|c|}{ Ascorbic } & \multicolumn{3}{|c|}{$\begin{array}{l}\text { Propionic } \\
\end{array}$} & \multicolumn{3}{|c|}{ Acetic } & \multirow{2}{*}{ control } \\
\hline & & $1 \%$ & $2 \%$ & $3 \%$ & $0.02 \%$ & $0.03 \%$ & $0.04 \%$ & $0.03 \%$ & $0.04 \%$ & $0.05 \%$ & \\
\hline \multicolumn{2}{|c|}{ Starch damage \% } & 5.20 & 5.17 & 5.22 & 5.25 & 5.28 & 5.29 & 5.25 & 5.3 & 5.28 & 5.18 \\
\hline \multirow{4}{*}{ 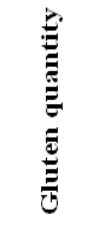 } & Wet $\%$ & 24.9 & 25.3 & 24.5 & 24.4 & 25.0 & 24.8 & 24.1 & 24.9 & 24.0 & 23.7 \\
\hline & Dry\% & 8.2 & 8.6 & 8.2 & 8.2 & 8.2 & 8.3 & 8.3 & 8.1 & 8.0 & 7.7 \\
\hline & $\begin{array}{l}\text { Hydration } \\
\text { ratio }\end{array}$ & 2.03 & 1.94 & 1.98 & 1.97 & 2.02 & 2.04 & 1.9 & 2.07 & 2.0 & 2.07 \\
\hline & Index $\%$ & 98.1 & 98.9 & 98.5 & 98.6 & 97.8 & 98.5 & 98.6 & 98.6 & 98.5 & 97.6 \\
\hline \multicolumn{2}{|c|}{ Protein sediment \% } & 30.0 & 31.0 & 30.0 & 30.0 & 31.0 & 30.0 & 30.0 & 30.0 & 30.0 & 29.8 \\
\hline \multicolumn{2}{|c|}{ Falling Number Sec. } & 365 & 321 & 311 & 339 & 340 & 330 & 350 & 335 & 351 & 390 \\
\hline \multirow{2}{*}{$\begin{array}{c}\text { Flowr } \\
\text { Color \% }\end{array}$} & White & 31.6 & 32.1 & 31.6 & 31.5 & 32.2 & 31.1 & 31.2 & 31.6 & 31.5 & 31.1 \\
\hline & yellow & 14.6 & 14.1 & 14.5 & 14.6 & 13.9 & 14.5 & 14.3 & 14.4 & 14.3 & 15.1 \\
\hline
\end{tabular}

\section{REFERENCES}

A.A.C.C. (2000): American Association of Cereal Chemists, Approved method of the AACC $10^{\text {th }}$ ed., Vol. 1, AACC, St. Paul, MN

A.O.A.C. (1990): Association of Official Analytical Chemists. Official Methods of Analysis. 15 ${ }^{\text {th }}$ Ed. Kenneth, H. ed. Published by A.O.A.C. Inc., Virginia, U.S.A.

A.O.A.C. (1995): Association of Official Analytical Chemists. Official Methods of Analysis. 16 ${ }^{\text {th }}$ Ed. Published by A.O.A.C. Benjamin Franklin station, Washington, D.C.

A.O.A.C. (2012): Association of Official Analytical Chemists. Official Methods of Analysis. 19 $9^{\text {th }}$ Ed. Published by A.O.A.C. North Frederick, U.S.A. 
Charles, F. (2005): Cereal grains and byproducts: what's in them and how are they processed? Cereal Grains and Byproducts pages 57-70.

D'Appolonia, B. L. and Emeritus, J. (1996): How Flour Affects Bread Quality Department of Cereal Science, North Dakota State University, Fargo, ND 58105, Lallemand Baking Update, Vol.1 / No. 17.

Debbouz, A.; Pitz, W. J.; Moore, W. R. and D'Appolonia, B. L. (1995): Effect of bleaching on durum wheat spaghetti quality. Cereal Chern. 72:128-131.

Dexter, J. E.; Matsuo, R. R. and D. G. Martin (1987): The relationship of durum wheat test weight to milling performance and spaghetti quality. Cereal Foods World 32: 772-777.

Dick, J. W. and R. R. Matsuo (1988): Durum wheat and pasta products. In: Wheat: Chemistry and Technology, Vol. II. $3^{\text {rd }}$ Ed. Y. Porneranz, ed. Am. Assoc. Cereal Chem., St. Paul, MN.

ES. (1986): Egyptian Standard of wheat grains. Egyptian Organization for Standardization and Quality Control, No. 1601, and its modification No. 2/2002. Arab Republic of Egypt.

ES. (2004): Egyptian Standard of durum wheat. Egyptian Organization for Standardization and Quality Control, No. 1649. Arab Republic of Egypt.

ES. (2006): Egyptian Standard of white flour for production of bread. Egyptian Organization for Standardization and Quality Control, No. 1419. Arab Republic of Egypt.

FAO / IAEA. (2001): Manual on the application of the HACCP system in mycotoxin prevention and Control. FAO Food and Nutrition Paper 73, Food and Agriculture Organization/International Atomic Energy Agency, Rome.

Gupta, R. K.; Sewa, Ram and Chauhan, D. S. (2002): Quality of Indian wheat. Doctorate of Wheat Research, Karnal - 132001, No. 14. 
Klich, M. A. (2002): Identification of Common Aspergillus Species. Centraal bureau voor Schimmelcultures, Utrecht, The Netherlands.

Mahmood, A. (2004): Acid-PAGE gliadin composition and cluster analysis for quality traits for different wheat varieties. Ph.D. Thesis, Dept. Food Technol. Univ.Agric. Faisalabad.

Milatovie, L. and Mondelli, G. (1991): Pasta technology today. ed. by Chiriotti-Poinerolo (To) -Italy.

Muhammad, Naeem, Safdar; Khalid, Naseem; Nouman, Siddiqui; Muhammad, Amjad; Tabassum, Hameed and Samina, Khalil (2009): Quality Evaluation of Different Wheat Varieties for the Production of Unleavened Flat Bread (Chapatti) Pakistan Journal of Nutrition 8 (11): 1773 -1778.

Nagarajan, S. (2005): Quality Characteristics of Indian Wheat, Quality and basic sciences, Vol. 4. Issue 9, Pages 79-86

Pasha, I. (2006): Biochemical characterization of Pakistani wheats in relation to grain hardness. Ph.D. Thesis, Dept. Food Technol. Univ. Agric. Faisalabad.

Randhawa, M. A. (2001): Rheological and technological characterization of new spring wheat grown in Pakistan for the production of Pizza. M.Sc. Thesis, Dept. Dept. Food Technol. Univ. Agric. Faisalabad.

Samson, R. A.; Hoekstra, E. S.; Frisrad, J. C. and Borg, O. F. (1995): Introduction to Food Borne Fungal Handbook, Fourth ed.

Serna-Saldivar, S. O. (2010): Cereal Grains Properties, Processing and Nutritional Attributes. CRC PressTaylor \& Francis Group pp. 249-251.

USDA (2013): U.S. DEPARTMENT OF AGRICULTURE, GRAIN INSPECTION HANDBOOK I. Grain Inspection, Packers and Stockyards Administration, Federal Grain Inspection Service Probe Sampling, Washington, D.C. 20090-6454. 
USDA (2013): U.S. Department of Agriculture, MOISTURE HANDBOOK Grain Inspection, Packers and Stockyards Administration 1400 Independence Ave., S. W. Washington, D.C. 20250-3600.

USDA (2016): U.S. Department of Agriculture, EQUIPMENT HANDBOOK. Grain Inspection, Packers and Stockyards Administration, S. W. Washington, D.C.

Vellaichamy, Chelladurai (2008): Identification of fungal infection in wheat using thermal imaging technique M.Sc., Theses, University of Manitoba (Canada), 110 pages; AAT MR50640.

Verma V. Ch. (2018): Applications and Investigations of Ozone in Cereal Grain Storage and Processing: Benefits and Potential Drawbacks. Int. J. Curr. Microbiol. App. Sci (2018) Special Issue-7: 50345041

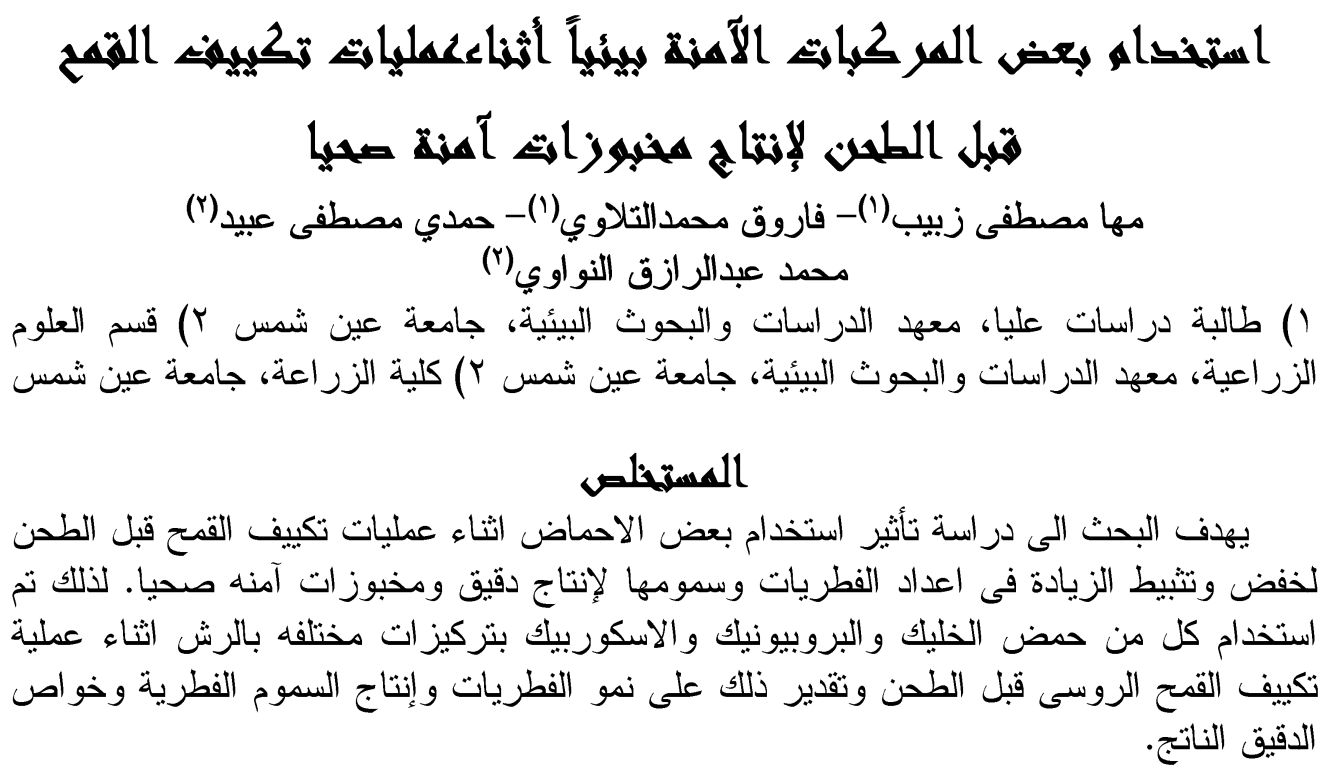


Journal of Environmental Sciences (JES)

Institute of Environmental Studies and Research, Ain Shams University

Zabib, Maha et al.

ولقد وجد ان استخدام حض (الخليك) بتركيز 0 .,. • ب يثبط نمو اسبراجلس فلافس تماما

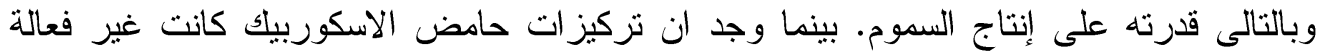

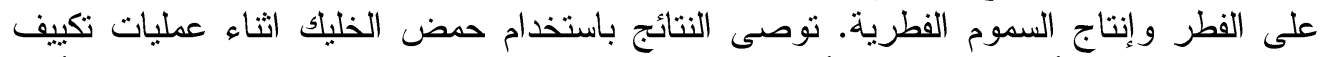

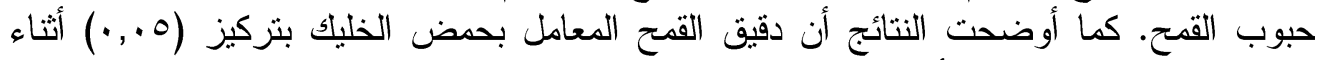

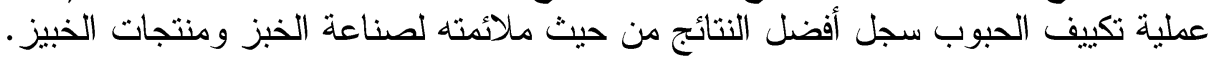

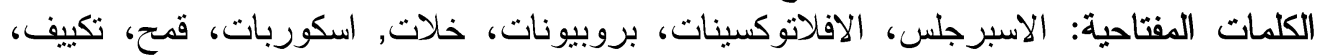
طحن. 